\title{
DRIFT-ARID: A method for assessing environmental water requirements (EWRs) for non-perennial rivers
}

\author{
Maitland Seaman', Marie Watson' ${ }^{1}$, Marinda Avenant ${ }^{1 *}$, Jackie King ${ }^{2}$, Alison Joubert ${ }^{3}$, Charles Barker ${ }^{4}$, Surina \\ Esterhuyse', Douglas Graham ${ }^{5}$, Marthie Kemp ${ }^{1}$, Pieter le Roux ${ }^{6}$, Bob Prucha7, Nola Redelinghuys ${ }^{8}$, Linda \\ Rossouw $^{9}$, Kate Rowntree ${ }^{10}$, Frank Sokolic ${ }^{1}$, Leon van Rensburg ${ }^{6}$, Bennie van der Waal ${ }^{10}$, Johan van Tol ${ }^{11}$ and \\ Tascha Vos ${ }^{1}$
}

${ }^{1}$ Centre for Environmental Management, University of the Free State, PO Box 339, Bloemfontein, South Africa ${ }^{2}$ Water Matters, PO Box 209, Constantia, South Africa

${ }^{3}$ Southern Waters, PO Box 12414, Cape Town, South Africa

${ }^{4}$ Geography Department, University of the Free State, PO Box 339, Bloemfontein, South Africa ${ }^{5} \mathrm{DHI}$, Agern Allé 5, DK-2970 Hørsholm, Denmark

${ }^{6}$ Soil, Crop and Climate Sciences Department, University of the Free State, PO Box 339, Bloemfontein, South Africa ${ }^{7} \mathrm{DHI}$ Water \& Environment, 141 Union Blvd, Suite 425, Lakewood, USA

${ }^{8}$ Social Sciences Department, University of the Free State, PO Box 339, Bloemfontein, South Africa ${ }^{9}$ Environmental and Water Quality Consultant, PO Box 16018, Panorama, 7506, South Africa ${ }^{10}$ Geography Department, Rhodes University, PO Box 94, Grahamstown, South Africa

${ }^{11}$ University of Fort Hare, Private Bag X1314, Alice, South Africa

\begin{abstract}
Environmental water requirement (EWR) assessment methods, for ascertaining how much water should be retained in rivers to sustain ecological functioning and desired levels of biodiversity, have mostly been developed for perennial rivers. Despite non-perennial rivers comprising about 30-50\% of the world's freshwater systems, data on their hydrology, biota and ecological functioning are sparse. Current EWR assessments require hydrological and other data that may not be available for such rivers and some adaptation in the methods used seems necessary. DRIFT is an EWR method for perennial (or near-perennial) rivers that has been developed in South Africa over the past two decades and is now widely applied nationally and internationally. When applied to the semi-permanent Mokolo River, challenges particular to, or accentuated by, non-perennial rivers included the reliable simulation of hydrological data, the extent of acceptable extrapolation of data, difficulties in predicting surface-water connectivity along the river, and the location and resilience of pools, as well as whether it was possible to identify a reference (natural) condition. DRIFT-ARID, reported on here, is an adaptation of the DRIFT approach to begin addressing these and other issues. It consists of 11 phases containing 29 activities.
\end{abstract}

Keywords: EWR, non-perennial, DRIFT, DSS

\section{INTRODUCTION}

South Africa's National Water Act (Act No. 36 of 1998) requires ecosystem-based management of water resources, which has driven the development of ecosystem-based tools (DWAF, 2002). One such tool is a method to assess environmental water requirements (EWRs) to maintain aquatic ecosystems at various levels of ecological condition. These levels can be assessed by stakeholders and government in terms of their implications to society, industry, biodiversity and agriculture, enabling decision-making on how any specific water system will be used in the future.

Methods for assessing the EWRs for perennial rivers have been under development locally since the 1980s and are now well established (Brown and Louw, 2011; Pienaar and King, 2011). One of the prominent international methods is DRIFT (Brown et al., 2008; King et al., 2014), a holistic, scenario-based approach that is essentially a data-management tool, allowing data and knowledge from a multidisciplinary team of specialists to be used effectively in a structured process. As with most EWR methods, DRIFT uses hydrological data as its starting point. Historical and present flow regimes are analysed for

\footnotetext{
* To whom all correspondence should be addressed. × 0514013939 ; e-mail: avenantmf@ufs.ac.za

Received 30 March 2015; accepted in revised form 25 May 2016
}

representative sites along the river of concern; our understanding of the relationships between flow, ecosystem and social indicators is captured in the form of response curves and housed in a DRIFT database (Decision Support System - DSS); and a range of water management scenarios are explored by simulating the new flow regimes and using the DSS to predict the outcome for each indicator at each site.

A method for establishing EWRs for non-perennial rivers is still lacking. Although such rivers are common worldwide, they are not well understood because they are often located in relatively unpopulated areas and their unpredictable flow patterns confound research planning (Williams 1988; Uys 1998; Davies and Day 1998; Tooth 2000; Alcácer 2004; Sheldon 2005). Many studies on the ecological characteristics and the hydrological variability of non-perennial rivers in arid zones have recently been published (Puckridge et al., 2000; Sheldon et al., 2002; Costelloe et al., 2003; Arthington and Balcombe, 2011; Rivers for Africa, 2013). Advances in the study of non-perennial rivers are progressing towards tools and methods of relevance to EWRs, such as the recognition of non-perennial rivers as important sources of biodiversity and providers of ecosystem services (Larned et al., 2010; Sheldon et al., 2010; McDonough et al., 2011; Steward et al., 2012; Arthington et al. 2014, Datry et al., 2014; Leigh et al., 2015) and the development of tools such as the MIRAGE Toolbox (Prat et al., 2014), but no formal EWR method 
has emerged. In South Africa, non-perennial rivers occur in arid and semi-arid areas with less than $500 \mathrm{~mm}$ of rain annually (Davies et al., 1994). The rainfall is erratic, river flow highly variable (Davies et al., 2006), and relevant hydrographic data sparse or non-existent. Knowledge on their ecological functioning is generally poor.

The research team found that DRIFT could possibly be used to assess EWRs of non-perennial rivers, but that six major challenges existed and some modification of the method was required (Rossouw et al., 2005; Seaman et al., 2010; 2013). The six challenges, and the way they were met, were as follows:

- Difficulties in simulating hydrological data. With few rain and flow gauges present in these arid areas, hydrological models are difficult to calibrate accurately. Monthly simulated hydrological data cannot easily be disaggregated to reveal the nature and timing of floods and the onset and end of low surface flows, resulting in data that are of low accuracy and confidence. In response we used catchment data, local knowledge and insights from soil scientists to better understand the hydrological functioning of the rivers.

- Understanding pools. When surface flow stops, pools act as refugia for aquatic and other life, but their location, nature, water chemistry, and persistence are poorly understood. Focused research can possibly explain why they occur where they do and why water chemistry and levels of persistence differ in the dry season, but it is difficult to gain these insights during data-sparse EWR assessments. Predictions on the consequences of the scenarios for these vital landscape features are thus not easily provided. Local knowledge and relevant indicators (invertebrates and fish that prefer pool habitat) for which we could get data were used as surrogates until more data become available.

- Connectivity. Pool connectivity is one of the most important attributes of non-perennial rivers, allowing for movement of organisms, mixing of gene pools and transport of nutrients and sediments along the system. With poor coverage of flow measurements, the extent of connectivity is often uncertain, confounding attempts to predict how organisms would be affected by the various scenarios. An integrated groundwater and surface water model was used to ascertain when flow would be expected between pools, together with Runoff Potential Units (RPUs), which provide some indication of what runoff could be expected in different parts of the catchment.

- Surface and groundwater interactions. Much of the nature of non-perennial rivers is predicated by the characteristics of their groundwater systems. Water may flow under the channel in aquifers, replenishing isolated pools and, at some times of the year, be the only source of any surface water. A groundwater-surface water hydrological model was developed to deal with this aspect.

- Extrapolation. Under such levels of physical, chemical and biological unpredictability, extrapolation of ecosystem attributes over long stretches of river is of uncertain value; e.g., each pool may be functioning differently. Any extrapolation would have to be at such a coarse level that it could be meaningless (e.g. a pool would have aquatic invertebrates - of uncertain families, genera and species). At present, understanding is limited mostly to the functioning of individual study sites. To address this, the only data used were those collected from each site and from similar sites within the same river reach. No extrapolation from other rivers in the same ecoregion or geomorphological zone was used.
Data from different aquatic habitats, such as riffles and pools, were not combined or compared.

- Establishing a reference condition. Many EWR methods compare present ecosystem condition and any future scenario condition with the natural or reference condition using categories of pristineness, because this allows quite dissimilar systems to be compared in terms of their ecological health. Non-perennial rivers, being understudied and notoriously variable and unpredictable, do not easily yield a reference condition. A two-pronged approach was used: firstly, using historical data and landscape clues to estimate a natural/reference condition and, secondly, using present-day condition as the starting point for scenario comparison, as that is what can be seen and measured.

The Seekoei River, an ephemeral tributary of the Orange River, was used to initially develop an adjusted EWR method. Method development continued with work on the semipermanent Mokolo River in the Limpopo Province (which flows for $72-87 \%$ of the year), leading to the evolution of a DRIFT-ARID method.

This is the first in a series of three papers, which should be read in sequence, and which present the structure and activities of DRIFT-ARID (first paper); a test application on the Mokolo River System (second paper) and the integrated groundwatersurface water hydrology component for input into the DRIFTARID method (third paper).

\section{METHOD}

DRIFT-ARID consists of 11 phases and 29 activities (Fig. 1).

\section{Phase 1: Initiate the EWR Study}

\section{Activity 1: Define the river in terms of non-perenniality}

At the earliest stage of an EWR, a decision has to be made as to whether the river is perennial or non-perennial. Where sufficient hydrological data of reasonable quality exist, ephemeral and semi-permanent rivers can be distinguished from perennial ones and each other (Table 1). Most rivers have at least one gauging weir with some data available, but if none are available, rainfall data and catchment hydrogeology could be used to model periods of no-flow (Croker et al., 2003).

Understanding the nature of the river helps guide the choice of a specialist EWR team (Table 2). Soil scientists and geohydrologists contribute valuable data for integrated groundwater-surface water modelling of non-perennial rivers. Macroinvertebrate and fish specialists may not be included in the team for episodic rivers and the inclusion of vegetation, mammal (wildlife) and terrestrial insect specialists could become more important (Prat et al., 2014).

\section{Phase 2: Set up the study}

Activities 3 and 4 follow the same principles as set out in the perennial method (DWA, 2013).

\section{Phase 3: Delineate the catchment and describe its hydrology}

In Phase 3, many features of the river and its catchment are considered in a series of activities designed to develop an understanding of the area and to structure the choice of representative sites for the EWR assessment. 


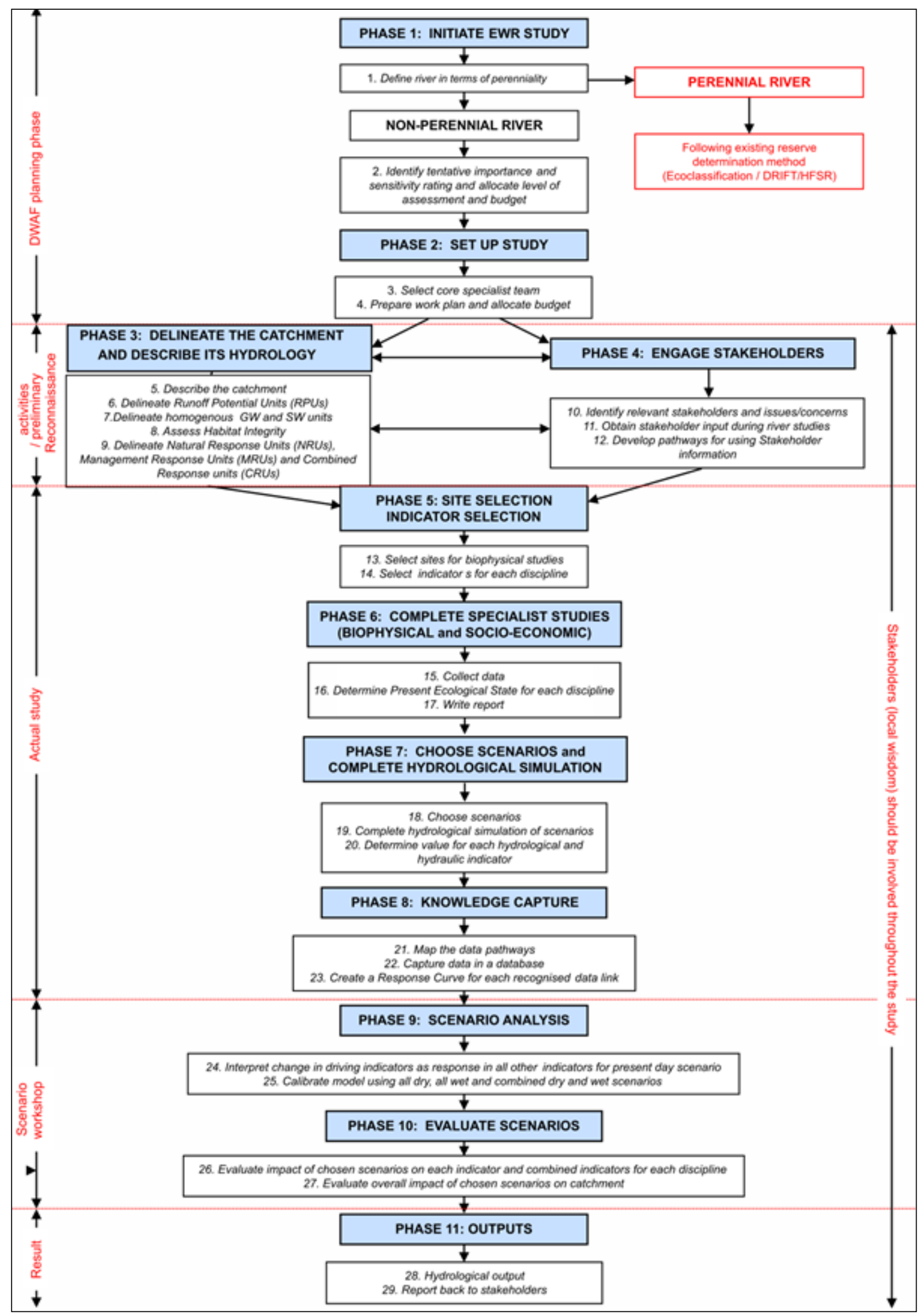

Figure 1

DRIFT-ARID method for determining the EWR for a non-perennial river 


\begin{tabular}{|l|l|l|l|l|}
\hline \multicolumn{5}{|c|}{ Categories of flow persistence, adapted from Rossouw et al. (2005) } \\
\hline River flow type & Perennial & \multicolumn{2}{|c|}{ Non-perennial } \\
\cline { 3 - 5 } & Semi-permanent & $\begin{array}{l}\text { Ephemeral } \\
\text { Episodic (range not yet } \\
\text { tested) }\end{array}$ \\
\hline $\begin{array}{l}\text { Degree of flow persis- } \\
\text { tence }\end{array}$ & $\begin{array}{l}\text { Usually perennial except } \\
\text { during extreme drought }\end{array}$ & $\begin{array}{l}\text { No flow 1\%-25\% of the } \\
\text { time }\end{array}$ & $\begin{array}{l}\text { No flow 26\%-75\% of the } \\
\text { time }\end{array}$ & $\begin{array}{l}\text { No flow at least 76\% of the } \\
\text { time; flows briefly only } \\
\text { after rain }\end{array}$ \\
\hline Examples & Orange River & $\begin{array}{l}\text { Mokolo (Limpopo) flows } \\
72-87 \% \text { of the time. }\end{array}$ & $\begin{array}{l}\text { Seekoei (Northern Cape) } \\
\text { flows 28\% of the time }\end{array}$ & $\begin{array}{l}\text { Swartdoring (Northern } \\
\text { Cape) flows 12\% of the time }\end{array}$ \\
\hline
\end{tabular}

\begin{tabular}{|l|c|c|c|c|}
\hline \multirow{2}{*}{ Specialist disciplines needed for an EWR assessment for a range of river types in South Africa } \\
\hline \multirow{2}{*}{ Specialist discipline } & \multirow{2}{*}{ Perennial } & \multicolumn{2}{c|}{ Non-perennial } \\
\cline { 2 - 5 } & & Semi-permanent & Ephemeral & Episodic \\
\hline \multirow{2}{*}{$\begin{array}{l}\text { EWR process manage- } \\
\text { ment team }\end{array}$} & Yes & Yes & Yes \\
\hline Groundwater & & & Yes (very important) & Yes (very important) \\
\hline Surface water & Yes & Yes & Yes & Yes \\
\hline Hydraulics & Yes & Yes & Yes & Yes \\
\hline Fluvial geomorphology & Yes & Yes & Yes (very important) & Yes (very important) \\
\hline Catchment geomorphology & Yes & Yes & Yes (very important) & Yes (very important) \\
\hline Soil science & Yes & Yes & Yes & Yes \\
\hline Water quality & Yes & Yes & Yes & Yes (very important) \\
\hline Riparian vegetation & Yes & Yes & Yes & No \\
\hline Macro-invertebrates & Yes & Yes & Yes & No \\
\hline Fish & Yes & Yes & Yes & Yes (very important) \\
\hline Socio-economics & Yes & Yes & No & Yes \\
\hline River-dependent wildlife & Yes & No & No & Yes \\
\hline Terrestrial insects & No & No & & \\
\hline
\end{tabular}

\section{Activity 5: Describe the catchment}

In non-perennial rivers, where data are limited and extrapolation to unstudied reaches cannot be done with confidence, new approaches may be of use to help describe and understand the system. One key characteristic of DRIFT-ARID is an intensive use of catchment data to help understand the nature of the river, particularly catchment geomorphology, which is one of the most important drivers of processes such as erosion, runoff and sediment movement.

As a starting point, any available data on catchment topography, climate, geology, soils, ecoregions (Kleynhans et al., 2004), water quality, vegetation types, land use, socioeconomic areas and similar concerns are used to summarise the characteristics of the basin and identify homogenous areas.

\section{Activity 6: Delineate Runoff Potential Units (RPUs)}

RPUs are areas within the catchment that can produce different amounts and patterns of runoff. They provide insight into the movement of water across the landscape and how it enters the river. RPUs follow drainage boundaries of sub-catchments within the basin, with a primary RPU consisting of basins at least one order lower than the highest one in the study area. RPUs are delineated using drainage features derived from a digital terrain model, and data on slope, cover, soil, and rainfall intensity, following the method in Seaman et al. (2010).

\section{Activity 7: Delineate homogeneous Groundwater and Sur- face Water Units}

One of the most important components in studies of a semiarid catchment is development of a conceptual idea of the main hydrological processes present. This will assist in determining not only homogeneous Surface Water Units, but also Groundwater Units. The basic information is gained from historical data, gauging weirs in the catchment, hydrological reports, ecoregion maps, geomorphological zones, land cover, dams and other infrastructure, recent groundwater reports, geology, groundwater presence, type of aquifers and springs, recharge potential, groundwater use and potential areas of surface and groundwater interaction (Seaman et al., 2013; Prucha et al., 2016).

\section{Activity 8: Assess Habitat Integrity}

The Index of Habitat Integrity Method of Kleynhans et al. (2008) is used in the assessment. 


\section{Activity 9: Delineate Natural Response Units (NRUs), Man- agement Response Units (MRUs) and Combined Response Units (CRUs)}

The specialists dealing with the natural landscape combine information on the ecoregions present at Level II (Kleynhans et al., 2007), geomorphological zones (Rowntree and Wadeson, 1999), macro-reaches (Dollar et al., 2006) and RPUs to produce a delineation of NRUs. In parallel, homogeneous units based on water quality, habitat integrity and socio-economic use of the catchment are combined to produce MRUs that provide insight into the degree of use and change of the river ecosystem. MRUs and NRUs are harmonised to produce CRUs. The process is described by Seaman et al. (2013).

The CRUs guide the selection of representative sites for the EWR assessment. Each site chosen represents its whole CRU, and the number chosen depends on the budget, level of EWR assessment approved, and the importance of the river system. The CRUs are similar to the Integrated Units of Analysis (Dollar et al., 2007), and the Reserve Assessment Units of Kleynhans and Louw (2007). Time might prove that these should be harmonised into one concept and one term.

\section{Phase 4: Engage stakeholders}

Stakeholders play a vital role in the EWR assessment in two main ways. Where data are few, they provide vital background information and local knowledge of the catchment, which helps guide the EWR team in terms of data collection and identification of suitable EWR indicators. They also give input into the selection of scenarios, and feedback after the scenario predictions have been made. A socio-economic specialist leads this phase, which is described in full by Seaman et al. (2010).

\section{Activity 10: Identify stakeholders and issues of concern}

Catchment stakeholders are identified from information collected on the catchment as well as through public announcements and meetings. Major concerns of any proposed water-resource development are identified during interviews, meetings and public participation workshops.

\section{Activity 11: Obtain stakeholders' input during river studies}

The socio-economic specialist develops a questionnaire to investigate understanding of people's use and knowledge of the basin. This contains social, economic and ecosystem questions for use in interviews with farmers, farm workers and other relevant stakeholders.

\section{Activity 12: Develop pathways for stakeholders' information to be included in later phases of the EWR}

The process by which stakeholders may share additional information with the team and receive updates on the EWR assessment is arranged.

\section{Phase 5: Site and indicator selection}

\section{Activity 13: Site selection}

If study sites cannot be set in every CRU, then priority CRUs have to be selected. Criteria that can be used for this could include:

\begin{tabular}{|c|c|l|}
\hline \multicolumn{2}{|c|}{$\begin{array}{c}\text { TABLE } 3 \\
\text { Example of importance ranking table completed by a spe- } \\
\text { cialist for CRUs identified }\end{array}$} \\
\hline \multicolumn{3}{|c|}{ Specialist field: Fluvial geomorphology } \\
\hline \multicolumn{2}{|c|}{ Criteria chosen } & $\begin{array}{l}\text { Scenic value } \\
\text { Potential for rehabilitation of flow regime } \\
\text { Areas which best characterise river types } \\
\text { Sensitivity to flow regime } \\
\text { Present Ecological State (PES) }\end{array}$ \\
\hline CRU & Ranking & Motivation \\
\hline A & 8 & Least sensitive to flow regime; scenic value \\
\hline B & 7 & $\begin{array}{l}\text { Highly modified channel; rehabilitation } \\
\text { potential }\end{array}$ \\
\hline C & 2 & $\begin{array}{l}\text { Important river type; scenic value; high } \\
\text { upstream water use }\end{array}$ \\
\hline D & 5 & Alternative for CRU E. Similar river type \\
\hline E & 3 & Important river type; scenic value \\
\hline F & 9 & Highly impacted by dam \\
\hline G & 4 & Alternative for CRU H; possible scenic value \\
\hline H & 1 & $\begin{array}{l}\text { Important river type; rehabilitation } \\
\text { potential - impacted by upstream dam }\end{array}$ \\
\hline I & 6 & Alternative for CRU H \\
\hline
\end{tabular}

- Areas with high numbers of people dependent on the river

- Areas of high conservation importance or great scenic beauty

- Areas in which major water-resource developments are planned or possible

- Areas where the river has rare species, habitats, or features

Each specialist is asked to rank the CRUs from 'important' to 'not important' using a scale from 1 (important) - \# (not important) where \# equals the number of CRUs identified in the catchment (Table 3).

The evaluations are combined and standardised to produce the final ranking with the most important CRU having the lowest score (Table 4). The number of sites agreed for the EWR assessment can then be allocated to the top-scoring CRUs.

A representative study site is chosen in each CRU, initially by desktop study of maps, satellite imagery, aerial photographs, and any other appropriate information, such as:

- Accessibility, both in terms of roads, and landowner's permission

- The degree to which the site would represent the CRU

- The availability of scientific and/or social data

The final choice of site locations is done at the river, preferably at times of low flow when the physical nature of the river bed can be seen. Additional criteria to consider at this stage are:

- Input from the landowner on the nature of the river

- The physical diversity that characterises the river within the CRU

- The presence of flow-sensitive habitats, such as riffles, if they exist

\section{Activity 14: Select indicators}

Each specialist selects a few key indicators for her/his discipline, and identifies any links with indicators from other disciplines. In each link there will be a driving indicator and a responding indicator: an indicator that is responding in one link can be a driver 


\begin{tabular}{|c|c|c|c|c|c|c|c|c|c|c|c|c|c|c|c|c|c|c|c|c|}
\hline \multicolumn{21}{|c|}{$\begin{array}{c}\text { TABLE } 4 \\
\text { Example of a combined and standardised specialist CRU ranking in terms of importance } \\
(\mathrm{O}=\text { original specialist ranking, } \mathrm{S}=\mathrm{standardised} \text { ranking })\end{array}$} \\
\hline \multirow[t]{2}{*}{ CRU } & \multicolumn{2}{|c|}{$\begin{array}{l}\text { Water } \\
\text { Quality }\end{array}$} & \multicolumn{2}{|c|}{ Soil } & \multicolumn{2}{|c|}{ Fish } & \multicolumn{2}{|c|}{$\begin{array}{c}\text { Macro- } \\
\text { inverte- } \\
\text { brates }\end{array}$} & \multicolumn{2}{|c|}{$\begin{array}{l}\text { Vegeta- } \\
\text { tion }\end{array}$} & \multicolumn{2}{|c|}{$\begin{array}{l}\text { Fluvial } \\
\text { Geomor- } \\
\text { phology }\end{array}$} & \multicolumn{2}{|c|}{$\begin{array}{l}\text { Catch- } \\
\text { ment } \\
\text { Geomor- } \\
\text { phology }\end{array}$} & \multicolumn{2}{|c|}{$\begin{array}{c}\text { Socio- } \\
\text { economic }\end{array}$} & \multicolumn{2}{|c|}{ Score } & \multicolumn{2}{|c|}{$\begin{array}{l}\text { Final } \\
\text { Rank }\end{array}$} \\
\hline & 0 & $\mathbf{S}$ & 0 & $S$ & 0 & S & 0 & S & 0 & $S$ & 0 & $S$ & 0 & $S$ & 0 & S & 0 & $S$ & 0 & $S$ \\
\hline H & 2.0 & 6.0 & 1.0 & 2.0 & 5.0 & 5.0 & 1.0 & 1.0 & 2.0 & 3.5 & 1.0 & 1.0 & 5.0 & 5.0 & 1.0 & 1.0 & 18.0 & 24.5 & 1.0 & 1.0 \\
\hline D & 2.0 & 6.0 & 1.0 & 2.0 & 3.0 & 3.0 & 2.0 & 2.0 & 2.0 & 3.5 & 5.0 & 5.0 & 6.0 & 7.5 & 2.0 & 2.0 & 23.0 & 31.0 & 2.0 & 2.0 \\
\hline G & 1.0 & 2.5 & 3.0 & 5.0 & 4.0 & 4.0 & 3.0 & 3.0 & 2.0 & 3.5 & 4.0 & 4.0 & 5.0 & 5.0 & 8.0 & 8.0 & 30.0 & 35.0 & 3.0 & 3.0 \\
\hline B & 1.0 & 2.5 & 9.0 & 8.0 & 1.0 & 1.0 & 6.0 & 6.0 & 6.0 & 8.0 & 7.0 & 7.0 & 2.0 & 1.0 & 4.0 & 4.0 & 36.0 & 37.5 & 6.0 & 4.0 \\
\hline $\mathbf{E}$ & 1.0 & 2.5 & 3.0 & 5.0 & 7.0 & 7.0 & 8.0 & 8.0 & 1.0 & 1.0 & 3.0 & 3.0 & 6.0 & 7.5 & 7.0 & 7.0 & 36.0 & 41.0 & 5.0 & 5.0 \\
\hline$C$ & 2.0 & 6.0 & 9.0 & 8.0 & 2.0 & 2.0 & 7.0 & 7.0 & 5.0 & 7.0 & 2.0 & 2.0 & 7.0 & 9.0 & 3.0 & 3.0 & 35.0 & 44.0 & 4.0 & 6.0 \\
\hline $\mathbf{F}$ & 1.0 & 2.5 & 3.0 & 5.0 & 8.0 & 8.0 & 9.0 & 9.0 & 2.0 & 3.5 & 9.0 & 9.0 & 3.0 & 2.5 & 6.0 & 6.0 & 41.0 & 45.5 & 8.0 & 7.0 \\
\hline I & 4.0 & 8.5 & 1.0 & 2.0 & 6.0 & 6.0 & 4.0 & 4.0 & 3.0 & 6.0 & 6.0 & 6.0 & 5.0 & 5.0 & 9.0 & 9.0 & 38.0 & 46.5 & 7.0 & 8.0 \\
\hline A & 4.0 & 8.5 & 9.0 & 8.0 & 9.0 & 9.0 & 5.0 & 5.0 & 7.0 & 9.0 & 8.0 & 8.0 & 3.0 & 2.5 & 5.0 & 5.0 & 50.0 & 55.0 & 9.0 & 9.0 \\
\hline TOT & & 45.0 & & 45.0 & & 45.0 & & 45.0 & & 45.0 & & 45.0 & & 45.0 & & 45.0 & & & & \\
\hline
\end{tabular}

in another link - for instance, aquatic invertebrates respond to a specific change in flow but help drive the abundance of some fish species (Fig. 2).

Selecting the most appropriate indicators and linkages requires in-depth interdisciplinary liaison and a joint agreement that the essence of the river and its users has been captured. Done well, this will substantially enhance and simplify the whole EWR assessment. A detailed list of possible indicators is provided in Seaman et al. $(2013 ; 2016)$.

\section{Phase 6: Complete specialist studies}

The chosen sites and indicators become the focus for specialist studies.

\section{Activity 15: Collect data}

The aim of the EWR assessment should be to focus the time available on key information that will help capture the essence of the flow-indicator relationships such as: species present; aquatic habitats available and the role that flow/inundation plays in the life-cycles of species. Specialists will use their own good-practice methods to collect and analyse the data, bearing in mind that all of these must relate to flow/inundation in some way. They should consult 'Phase 8: Knowledge Capture', to ensure that their data can provide information in the form needed.

\section{Activity 16: Ascertain the Present Ecological State (PES)}

A rating (PES) is determined for the river ecosystems to indicate the condition or 'health'. This rating indicates how far removed from 'natural', i.e. degraded, the ecosystem presently is.

In order to do this, we have to have some understanding of what 'natural' means. As mentioned above in the list of challenges, it is often virtually impossible to describe a median natural state for non-perennial rivers as they may vary so much from point to point and year to year. Great variability and unpredictability is indeed their natural condition. Nevertheless, some measure of 'natural' is needed and we have found that specialists experienced in these systems can use historical information, photographs, landscape and other clues to reach intuitive conclusions on how degraded their study systems are.

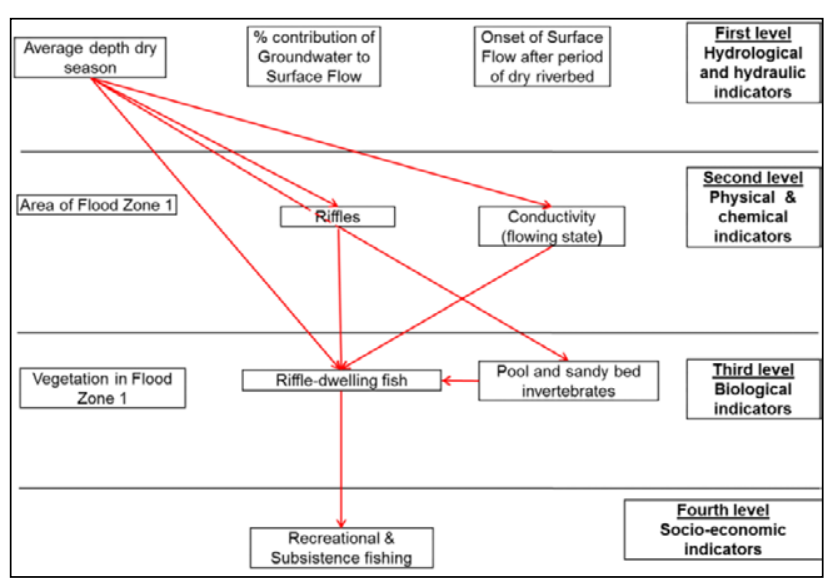

\section{Figure 2}

Example of levels of indicators chosen and some possible links

With this in mind, they then adjust or use current methods available for perennial rivers to determine the PES category (Table 5), providing explanations and justification as described by Seaman et al. (2010).

\section{Activity 17: Write report}

Each specialist submits a report on the methods; indicators chosen, with reasons; data collected and PES from their discipline.

\section{Phase 7: Choose scenarios and complete hydrological simulation of scenarios}

The DRIFT-ARID DSS analyses possible management (usually development) scenarios. Each scenario begins with the simulation of its flow regime, followed by the predicted physical, chemical and biological responses to that.

\section{Activity 18: Choose scenarios}

A prioritised list of about four scenarios is a useful starting point, with these being as dissimilar as possible in terms of the likely future changes they will drive. The choice of scenarios should be made in consultation with the client and stakeholders. Input from the hydrologist and modellers is important, as 
TABLE 5

Generic ecological categories for PES (modified from Kleynhans, 1996; 1999)

\begin{tabular}{|c|l|l|}
\hline $\begin{array}{c}\text { Ecological } \\
\text { Category }\end{array}$ & Description score & \% of natural \\
\hline A & Unmodified, natural & $\begin{array}{l}\text { Largely natural with few modifications. A small change in natural habitats and biota may have taken } \\
\text { place but the ecosystem functions are essentially unchanged. }\end{array}$ \\
\hline B & $\begin{array}{l}\text { Moderately modified. Loss and change of natural habitat and biota have occurred, but the basic } \\
\text { ecosystem functions are still predominantly unchanged. }\end{array}$ & $80-89$ \\
\hline C & Largely modified. A large loss of natural habitat, biota and basic ecosystem functions has occurred. & 60-79 \\
\hline D & Seriously modified. The loss of natural habitat, biota and basic ecosystem functions is extensive. & 20-39 \\
\hline E & $\begin{array}{l}\text { Critically / extremely modified. Modifications have reached a critical level and the system has } \\
\text { been modified completely with an almost complete loss of natural habitat and biota. In the worst } \\
\text { instances, the basic ecosystem functions have been destroyed and the changes are irreversible. }\end{array}$ & $0-19$ \\
\hline F & &
\end{tabular}

the scenarios chosen must be amenable to hydrological modelling and potentially be able to demonstrate quite different future flow regimes. With the DSS set up and an initial set of scenarios completed, additional ones can easily be created to further explore options of interest.

\section{Activity 19: Complete hydrological simulation of scenarios}

The whole EWR assessment is dependent on the hydrological data provided. With very few such data available on non-perennial rivers in South Africa, Hughes (2008) concluded that any model used to simulate flows would produce results of relatively low confidence. Nevertheless, daily flow data are needed. We recognise that the simulations of daily flows may be imprecise, but the greater requirement is that they characterise the flow regime at a time step that the living system experiences and reacts to (King et al., 2014). The modeller should collaborate with geohydrologists and hydrologists with extensive experience of arid-zone rivers in order to best encapsulate the essence of the present and possible future flow regimes of the river. If possible, an integrated groundwater-surface water hydrological model could be used (Seaman et al., 2013; Prucha et al., 2016). Useful outputs would relate to surface discharge, river stage, groundwater flow, depth to groundwater in channel, and baseflow into river.

\section{Activity 20: Determine value for each hydrological and hydraulic indicator}

Among the indicators chosen are a set of hydrological ones. These capture the team's opinion on what aspects of the river's flow regime most influence the functioning of the ecosystem. The DRIFT DSS for perennial rivers contains a module that calculates mean annual values for a standard set of flow indicators. This facility is not yet available for non-perennial rivers, where different attributes of flow might be more relevant, so the appropriate flow indicators have to be chosen and their mean values calculated by the team hydrologist. Flow indicators, such as onset of no-flow conditions and depth of water table in the channel, may be chosen (Seaman et al., 2013; 2016). Similar annual values are calculated for hydraulic indicators, e.g., average water depth in the wet season.

\section{Phase 8: Knowledge capture}

We will probably never have enough data to develop a complete understanding of the functioning of river ecosystems, and river scientists cannot indefinitely delay providing inputs to waterresource management because of this. Rather, recognising the growing body of knowledge on rivers, we need to capture that as best we can to help guide their management. DRIFT's version of this is the creation of response curves (Brown et al., 2008; Seaman et al., 2013), as explained below.

\section{Activity 21: Map the data pathways}

The specialists construct a flow diagram that illustrates their understanding of the driving and responding links between all their indicators (see Fig. 2). The final result reveals how information flows through the DRIFT-ARID application as the team members make their predictions. In effect, this is the layout of a simplified 'ecosystem model'.

\section{Activity 22: Capture data in a database}

The DRIFT-ARID DSS is populated with the values for the hydrological indicators: the median, maximum and minimum values and points over the period of hydrological simulation, for all sites (Table 6). This establishes the baseline values of the flow indicators, thereby providing the starting point from which the reactions of all other indicators will be described.

To enable these ecosystem reactions to be predicted, the names of all the other indicators and their links to flow and each other are recorded in the DRIFT-ARID database. Each DRIFT application is unique in its selection of indicators and links, but individual DRIFT-ARID applications may eventually lead to a generic set of flow and other indicators from which to choose, in much the same way as has happened for perennial rivers.

\section{Activity 23: Create a response curve for each recognised indicator link}

For each link between indicators (arrows in Fig. 2) a response curve has to be drawn. Each response curve (Fig. 3) describes how a responding indicator will respond to a driving indicator, and is based on the assumption that the rest of the ecosystem will remain unchanged. The curves are created by specialists with a working knowledge of the river ecosystem and its users; are graphic and explicit with supporting explanations; and are amenable to adjustment as knowledge increases.

The starting point of a response curve is present day (PD) flow conditions. In Fig. 3, the oval represents a PD median dry-season minimum discharge of $30 \mathrm{~m}^{3} \cdot \mathrm{s}^{-1}$; the value of the 
responding indicator (in this case Fish Guild A) under these conditions is always given as zero. Severity ratings (Table 7) are then used to draw the response curve describing possible change in the indicators from the $\mathrm{PD}$ position. The specialists draw in the shape of the response curves, using the severity ratings and guided by the PD standard deviation and PD range of the driving indicator (in this case, dry season minimum discharge).

\section{Phase 9: Scenario analysis}

During scenario analysis and continuing with the example given in Fig. 3, the DSS takes the actual year-by-year values for median dry-season minimum flow and reads off the corresponding value for the severity of change to the abundance of Fish Guild A. The change in abundance is then calculated as a percentage change from PD which is based on actual data. The result is a time series of annual abundance values for the Fish Guild that is as long as the hydrological simulation. The same happens for all relevant linked indicator pairs.

\section{Activity 24: Interpret change in driving indicators as re- sponse in all other indicators for present-day scenario}

Responses from all the driving response curves are aggregated per indicator to give an overall response per season and year. Figure 4, for instance, shows how Rapid/Riffle dwelling fish are expected to have changed in abundance over the 50 years represented by PD hydrological conditions. Such time series can be used to help calibrate the DSS by referring back to known field data.

\section{Activity 25: Calibrate model using 'all dry', 'all wet' and 'com- bined dry and wet'scenarios}

The average score of the PD scenario should be in the region of $100 \%$ (shown top right in Fig. 4), which equates to zero on the response curve. The specialists may need to calibrate their module by adjusting some of their response curves to achieve this.

Hydrology data from three fictitious scenarios are also included in the DSS to aid further calibration by the specialists: the 'all wet' scenario includes values from the wettest years throughout the time series so that it appears as though the river has wet years throughout; the 'all dry' scenario includes values from the driest years throughout the time series; and the 'combined wet and dry' scenario includes values from the wettest years for half of the time series and from the driest years for the remainder.
TABLE 6

Hypothetical DRIFT entries, from the simulated hydrological record, of attributes of the flow indicator 'duration of no surface flow', for one EWR site

\begin{tabular}{|l|c|}
\hline $\begin{array}{l}\text { Attributes of the flow indicator 'duration of no sur- } \\
\text { face flow' }\end{array}$ & Days \\
\hline Minimum possible & 0 \\
\hline Minimum under present day conditions & 60 \\
\hline Interim point & 69 \\
\hline Median under present day conditions & 79 \\
\hline Interim point & 114 \\
\hline Maximum under present day conditions & 149 \\
\hline Maximum possible & 176 \\
\hline
\end{tabular}

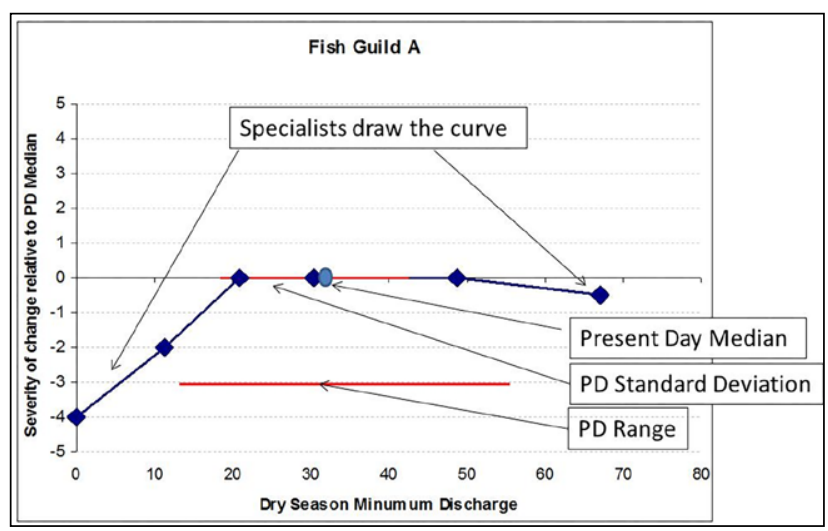

Figure 3

An example of a DRIFT response curve indicating the response of FishGuild $A$ to minimum dry-season flows. $P D=$ present day

\section{Phase 10: Evaluate scenarios}

With calibration of the DSS complete, the chosen scenarios can be investigated. By putting in the relevant simulated flow regime and linking it to the relevant response curves to provide predictions of ecological change.

\section{Activity 26: Evaluate the impact of scenarios on each indica- tor and each discipline}

During a workshop, the specialists evaluate the DRIFT predictions of change for each scenario, site, and indicator, and make revisions to the response curves if deemed necessary. The DSS also provides a summary of predicted changes per discipline.

\begin{tabular}{|c|c|c|c|}
\hline \multicolumn{2}{|c|}{\begin{tabular}{c} 
TABLE 7 \\
Severity ratings \\
\hline Severity rating
\end{tabular}} & $\begin{array}{c}\text { Equivalent loss } \\
\text { (i.e. abundance retained) }\end{array}$ & Equivalent gain \\
\hline 0 & Severity change & No change & No change \\
\hline 1 & Negligible & $80-100$ & $26-67$ \\
\hline 2 & Low & $60-79$ & $68-250$ \\
\hline 3 & Moderate & $40-59$ & $251-500$ \\
\hline 4 & Large & $20-39$ & $501-\infty$ (to pest proportions) \\
\hline 5 & Very large & $0-19$ & 26 \\
\hline
\end{tabular}




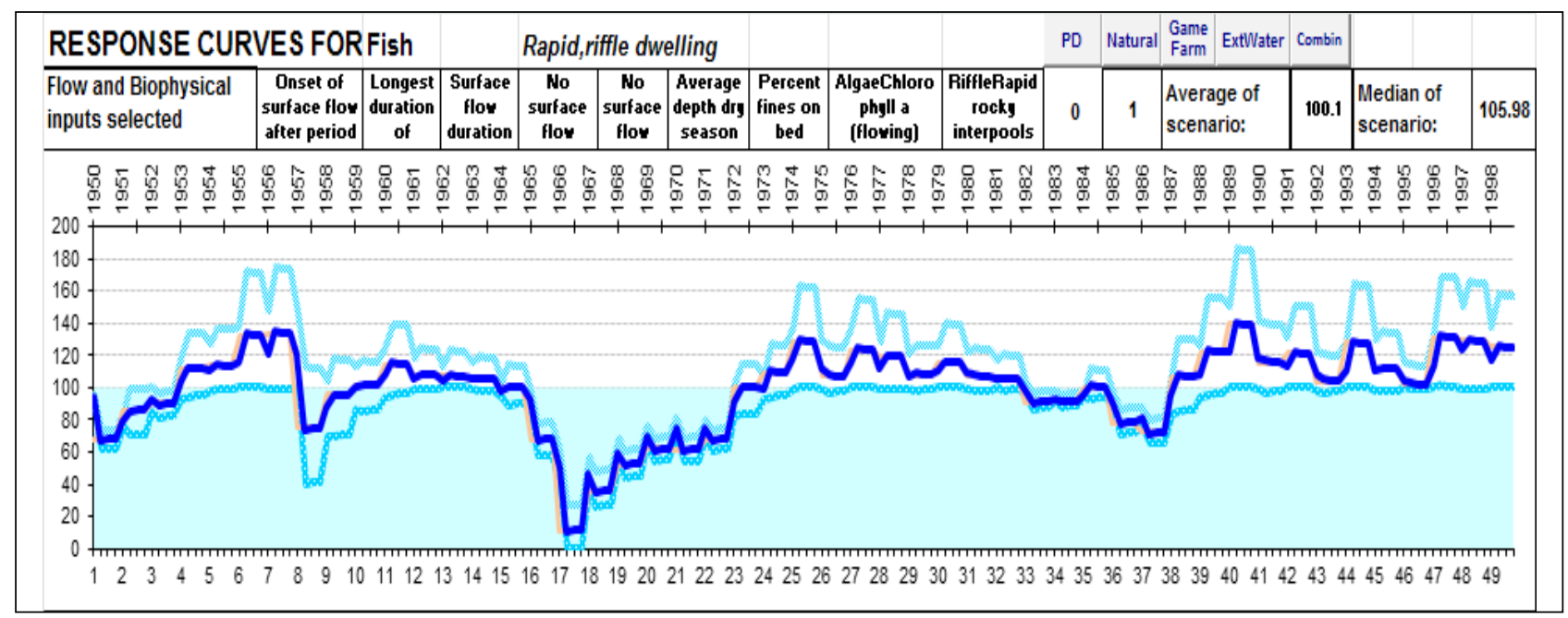

Figure 4

Time series of overall response of Rapid/Riffle dwelling fish species under the PD. The dark line is the overall response to all indicators and the pale lines indicate the range. $X$-axis = years, $Y$-axis = percentage change in fish abundance from median PD (100\%)

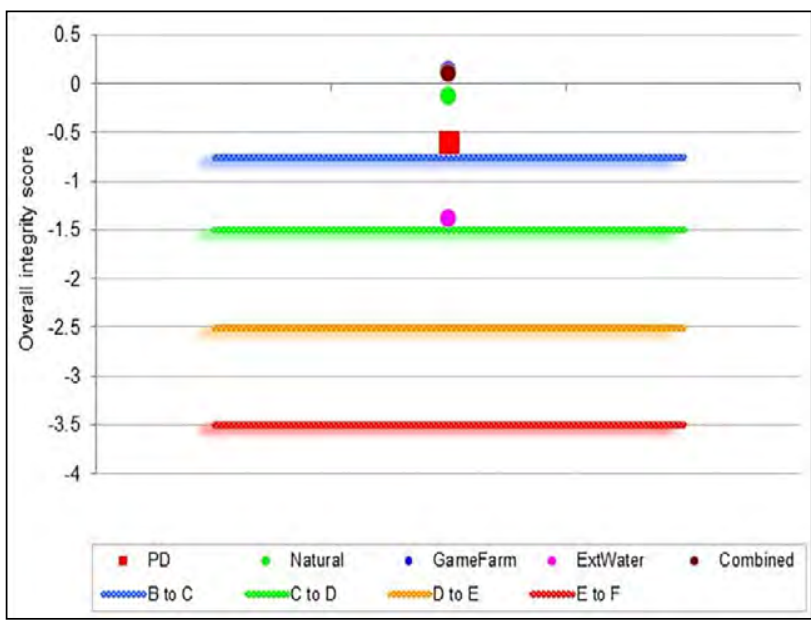

Figure 5

The predicted overall ecosystem integrity for a river site under four scenarios. $P D=$ present day, Natural = reference scenario, GameFarm = game farm scenario, ExtWater = external water scenario, Combined = game farming and external water scenarios combined. Ecological Categories $A$ to Fas per Table 5

\section{Activity 27: Evaluate overall impact of chosen scenarios on catchment}

The EWR team evaluates the impact of the scenarios on the overall integrity of the river ecosystem (Fig. 5) using the ecological condition categories described in Table 5. The fuzzy horizontal lines indicate the approximate position where the ecosystem moves from one condition category to the next. For example, the blue line shows that ecosystem health drops from a $\mathrm{B}$ to a $\mathrm{C}$ at an integrity value of about -0.8 . The Baseline (PD) condition of each site is shown by a red square.

\section{PHASE 11: Outputs}

The outcome of the DRIFT-ARID application is summarised in various ways, to help make it accessible to a wide range of stakeholders.

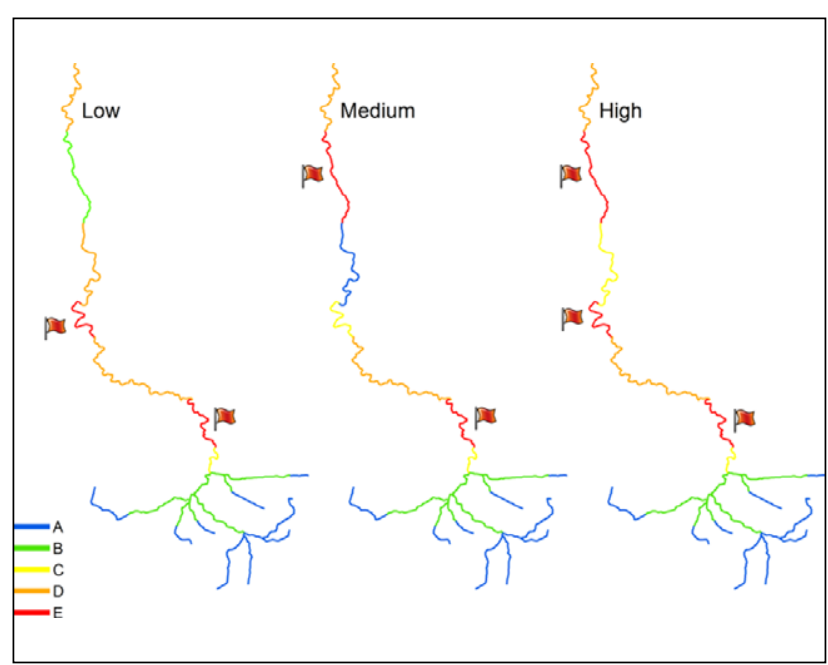

Figure 6

A hypothetical summary of DRIFT-predicted changes in ecosystem condition for chosen (low, medium and high water use) scenarios for a river system. A to E ecosystem conditions as per Table 5. Red flags indicate degraded reaches.

\section{Activity 28: Hydrological and ecological outputs}

The hydrological predictions alone present many insights as to what the future of a river could be under different scenarios. As an example (using a site in the Okavango Basin as illustration), three possible future water management regimes show how the dry season could start earlier, its minimum flow decrease and the vital flooding that maintains the Okavango Delta reduce (Table 8).

The predictions of ecological change can then be summarised in ways such as colour-coded maps of change (Fig. 6). Such maps do not analyse how a river system has degraded in the past but rather how it could do so in the future, thereby providing decisionmakers with information that has not been available to them until recently.

\section{Activity 29: Report back to stakeholders}

The outcome of the chosen scenarios is presented to the stakeholders in ways that facilitate discussion and negotiation about the future of the river. 
TABLE 8

Selected predictions of possible changes in flow indicators for a site on the Okavango River under three possible future watermanagement regimes (King et al., 2009)

\begin{tabular}{|c|c|c|c|c|c|}
\hline Flow indicator & PD & $\begin{array}{c}\text { Low water } \\
\text { use }\end{array}$ & $\begin{array}{c}\text { Medium } \\
\text { water use }\end{array}$ & $\begin{array}{l}\text { High water } \\
\text { use }\end{array}$ & Comment \\
\hline Dry season onset & Aug & July & July & June & $\begin{array}{l}\text { Progressively earlier: } 1,3 \text {, and } 7 \text { weeks earlier } \\
\text { than PD }\end{array}$ \\
\hline Dry season minimum flow $\left(\mathrm{m}^{3} \mathrm{~s}^{-1}\right)$ & 114 & 101 & 93 & 21 & Progressive decline: $89 \%, 82 \%, 18 \%$ of PD \\
\hline Flood type 1: no flood & 1 & 1 & 1 & 3 & \multirow{6}{*}{$\begin{array}{l}\text { Numbers represent the number of occur- } \\
\text { rences in the } 43 \text {-year hydrological simula- } \\
\text { tions. Result shows a progressive shift away } \\
\text { from higher floods to lower ones. }\end{array}$} \\
\hline Flood type 2: very low & 2 & 2 & 4 & 7 & \\
\hline Flood type 3: low & 10 & 10 & 17 & 21 & \\
\hline Flood type 4 : moderate & 19 & 20 & 11 & 3 & \\
\hline Flood type 5: high & 2 & 2 & 5 & 8 & \\
\hline Flood type 6: very high & 9 & 8 & 5 & 1 & \\
\hline
\end{tabular}

\section{CONCLUSIONS}

The application of DRIFT to assess EWRs for perennial rivers is now well documented (Brown et al., 2006, 2008; King and Brown, 2010; King et al., 2014) and is not repeated. Rather, we focus here on its application to non-perennial rivers and the necessity to adjust the approach, largely due to the paucity of data on such systems but also because of their different nature. This first attempt to develop a DRIFT-ARID method has relied heavily on the established DRIFT method, and has provided very useful experience on how to adapt this for arid rivers. Seaman et al. (2013) provides more details.

Some of the main lessons learnt are as follows.

- Ascertaining the degree of perenniality of a river at the outset is a vital step in the DRIFT-ARID method (Seaman et al., 2010; 2013). For semi-permanent rivers, such as the Mokolo River, the perennial EWR methods (e.g. DRIFT) could be used with success but the greater the degree of non-perenniality, the less the likelihood that data sets needed would be available or dependable.

- Because of the paucity of data and uncertainty of the validity of extrapolation (Lamprecht, 2009), the specialists included in the non-perennial river teams must have extensive experience of the specific rivers being addressed or neighbouring similar ones.

- Where measured flow data are rare or non-existent, RPUs may be introduced to aid catchment delineation and the choice of sites. They provide insights on catchment hydrology and, specifically, on areas where the pattern and intensity of runoff are expected to change along the river.

- The stakeholder process is extremely important as it provides additional information, insights and data for specialists to use in data-deficient catchments.

- When developing the baseline hydrological information for the assessment in cases where hydrological data are scarce, the challenges are many and substantial (Hughes, 2008). Ideally, an integrated groundwater-surface water hydrological model would be used to produce daily or sub-daily data on a range of chosen flow indicators, such as onset of surface flow after a period of dry river bed. Such a model was set up for the Mokolo River study and conclusions on the flow indicators chosen, its success and possible future use are reported in Seaman et al. (2013) and Prucha et al. (2016).

- A GIS specialist is a very useful team member, combining information from the NRUs and MRUs to produce the combined CRUs in a structured and clear way.

\section{RECOMMENDATIONS}

DRIFT has been applied to a large array of rivers, each with its unique challenges. The refinement of the perennial method spanned nearly two decades resulting in DRIFT in its current state. It is envisaged that DRIFT-ARID will similarly evolve as it is tested on additional arid rivers and understanding of their functioning evolves. Thus, an important recommendation is to support this learning-by-doing approach and complete more EWR assessments for arid rivers.

Some types of non-perennial rivers have sufficient water in the dry season to make them attractive as water sources for people. The water is often held in surface pools, which are vital in the functioning of the river ecosystem, acting as water sources for terrestrial wildlife and livestock in an arid landscape and refugia for aquatic life. An alternative method for determining the EWR for such rivers based on pools, and acceptable levels of abstraction from them, could be explored. Fundamental studies in all disciplines on such pools (permanent and temporary) are needed.

A recurring theme throughout the current project has been that more data are needed - to improve the hydrological modelling, the methods used for the determination of PES, the selection and hydrological simulation of scenarios, and the construction of response curves. Much of this would improve through assessment of many rivers with concomitant testing and enhancing of the methods. It is crucial that fundamental data continues to be collected. Universities could support post-graduate studies in each discipline on the links between species, habitat and flow. The need is to better understand the critical stages, thresholds and water availability in these rivers that affect the life cycles of river-dependent plants and animals and the consequent impacts this could have on people.

\section{ACKNOWLEDGEMENTS}

The Centre for Environmental Management and the Water Research Commission are acknowledged for supplying funds and facilities. We thank Southern Waters for assisting in the development of the DRIFT-ARID model.

\section{REFERENCES}

ALCÁCER C (2004) Summary of Round Table 1: Ecohydrology and hydrogeology drivers of ephemeral rivers - management implications. Scientific Workshop on the Provision of Environmental Flows in Mediterranean Ephemeral Rivers, 18 September 2004, Madrid at the UICN Centre for Mediterranean Cooperation. 
ARTHINGTON AH and BALCOMBE (2011) Extreme hydrologic variability and the boom and bust ecology of fish in arid zone floodplain rivers: a case study with implications for environmental flows, conservation and management. Ecohydrology 4 708-720. http://dx.doi. org/10.1002/eco.221

ARTHINGTON AH, BERNARDO JM and ILHéU M (2014) Temporary rivers: linking ecohydrology, ecological quality and reconciliation ecology. River Res. Appl. 30 (10) 1209-1215. http://dx.doi.org/10.1002/ rra.2831

BROWN C, PEMBERTON C, BIRKHEAD A, BOK A, BOUCHER C, DOLLAR E, HARDING W, KAMISH W, KING J, PAXTON B and co-authors (2006) In support of water resource planning - highlighted key management issues using DRIFT: A case study. Water SA 32 (2) 181-192.

BROWN CA, JOUBERT AR, PEMBERTON CW, GREYLING AJ and KING JM (2008) DRIFT USER MANUAL V2.0: Biophysical Module for predicting overall river condition in small to medium sized rivers with relatively predictable flow regimes (incorporating updates). Southern Waters, Cape Town.

BROWN C and LOUW D (2011) Tools and procedures for Resource Directed Measures. In: King J and Pienaar H (eds) Sustainable Use of South Africa's Inland Waters. WRC Report No. TT 491/11. Water Research Commission, Pretoria.

COSTELLOE JF, GRASON RB, ARGENT RM and McMAHON TA (2003) Modelling the flow regime of an arid zone floodplain river, Diamantina River, Australia. Environ. Model. Softw. 18 693-703. http://dx.doi. org/10.1016/S1364-8152(03)00071-9

CROKER KM, YOUNG AR, ZAIDMAN MD and REES HG (2003) Flow duration curve estimation in ephemeral catchments in Portugal. Hydrolog. Sci. J. 48 (3) 427-439. http://dx.doi.org/10.1623/ hysj.48.3.427.45287

DAVIES B and DAY J (1998) Vanishing Waters. University of Cape Town Press, Cape Town. 487 pp.

DAVIES BR, THOMS MC, WALKER KF, O'KEEFFE JH and GORE JA (1994) Dryland rivers: Their ecology, conservation and management. In: Calow P and Petts GE (eds) The Rivers Handbook (Vol. 2). Blackwell Scientific, Oxford. 523 pp.

DAVIES BR, O'KEEFFE JH and SNADDON CD (2006) River and stream ecosystems in southern Africa: Predictably unpredictable. In: Cushin CE Cummins KW and Minshall GW (eds) River and Stream Ecosystems of the World. University of California Press, Berkeley. 817 pp.

DATRY T, LARNED ST and TOCKNER K (2014) Intermittent rivers: A challenge for freshwater ecology. Bioscience 64 (3) 229-235. http:// dx.doi.org/10.1093/biosci/bit027

DWAF (DEPARTMENT of WATER AFFAIRS AND FORESTRY, SOUTH AFRICA) (2002) Resource Directed Measures for protection of water resources: river ecosystems - revision of a quantity component. Department of Water Affairs and Forestry, Pretoria.

DWA (DEPARTMENT OF WATER AFFAIRS, SOUTH AFRICA) (2013) A desktop Assessment of the Present Ecological State, Ecological Importance and Ecological Sensitivity per Sub Quaternary Reaches For Secondary Catchments in South Africa. Compiled by RQS-RDM. Department of Water Affairs, Pretoria.

DOLLAR LH, DOLLAR ESJ and MOOLMAN L (2006) Development of an automated procedure for defining changes in river longitudinal profiles. Water SA 32 (3) 395-402.

DOLLAR ESJ, BROWN CA, TURPIE JK, JOUBERT AR, NICOLSON CR and MANYAKA SM (2007) The development of the Water Resource Classification System (WRCS) Volume 1. Overview and 7-step classification procedure. CSIR Report No. CSIR/NRE/WR/ ER/2006/0187A/C. Department of Water Affairs and Forestry, Pretoria

HUGHES DA (2008) Hydrological information requirements and methods to support the determination of environmental water requirements in ephemeral river systems. WRC Report No. KV 205/08. Water Research Commission, Pretoria.

KING JM and BROWN CA (2010) Integrated basin flow assessments: concepts and method development in Africa and South-east Asia. Freshwater Biol. 55 (1) 127-146. http://dx.doi. org/10.1111/j.1365-2427.2009.02316.x

KING JM, BROWN CA, PAXTON BR and FEBRUARY RJ (2004) Development of DRIFT, a scenario-based methodology for environmental flow assessments. WRC Report No. 1159/1/04. Water Research Commission, Pretoria
KING JM, BROWN CA and BARNES J (2009) Final IFA Project Report. Report 08-2009 EPSMO/BIOKAVANGO. Okavango Basin Environmental Flows Assessment Project, OKACOM, Maun, Botswana.

KING JM, BEUSTER H, BROWN C and JOUBERT AJ (2014) Pro-active management: the role of environmental flows in transboundary cooperative planning for the Okavango River system. Hydrolog. Sci. J. 59 (3-4) 786-800. http://dx.doi.org/10.1080/02626667.2014.888069

KLEYNHANS CJ (1996) A qualitative procedure for the assessment of the habitat integrity status of the Luvuvhu River (Limpopo system, South Africa). J. Aquat. Ecosyst. Health 5 41-54. http://dx.doi.org/10.1007/ BF00691728

KLEYNHANS CJ (1999) R7: Assessment of Ecological Importance and Sensitivity. Resource Directed Measures for Protection of Water Resources: River Ecosystems. Department of Water Affairs and Forestry, Pretoria.

KLEYNHANS CJ and LOUW MD (2007) River reach demarcation, delineation and site suitability. Appendix A: Comprehensive Reserve determination study for selected water resources (rivers, groundwater and wetlands) in the Inkomati Water Management Area, Mpumalanga. Sabie and Crocodile systems: resource unit delineation. Report No. 26/8/3/10/12/006. Department of Water Affairs and Forestry, Pretoria.

KLEYNHANS CJ, THIRION C and MOOLMAN J (2004) The development and refinement of a Level II ecoregion map for South Africa together with geomorphological zones for all major rivers. Project No. 2002-392. Resource Quality Services. Department of Water Affairs and Forestry, Pretoria.

KLEYNHANS CJ, THIRION C, MOOLMAN J and GAULANA L (2007) A Level II River Ecoregion Classification System for South Africa, Lesotho and Swaziland. Report No. N/000/00/REQ0XXX. Resource Quality Services. Department of Water Affairs and Forestry, Pretoria.

KLEYNHANS CJ, LOUW MD and GRAHAM M (2008) Module G: EcoClassification and EcoStatus Determination in River EcoClassification: Manual for Index of Habitat Integrity (Section 1, model manual). Department of Water Affairs and Forestry, Pretoria.

LAMPRECHT E (2009) Data extrapolation from macro-invertebrate communities in the Upper Orange River catchment area, South Africa. Is it viable? Unpublished thesis, Masters in Environmental Management, University of the Free State, South Africa.

LARNED ST, DATRY T, ARSCOTT DB and TOCKNER K (2010) Emerging concepts in temporary river ecology. Freshwater Biol. 55 717-738. http://dx.doi.org/10.1111/j.1365-2427.2009.02322.x

LEIGH C, BOULTON AJ, COURTWRIGHT JL, FRITZ K, MAY CL, WALKER RH and DATRY T (2015) Ecological research and management of intermittent rivers: a historical review and future directions. Freshwater Biol. DOI: 10.1111/fwb.12646

MCDONOUGH OT, HOSEN JD and PALMER MA (2011) Temporary streams: the hydrology, geography and ecology of non-perennially flowing waters. In: Elliot HS and Martin LE (eds) River Ecosystems: Dynamics, Management and Conservation. Nova Science Publishers. Hauppauge, New York.

PIENAAR H and KING J (2011) Giving effect to Resource Directed Measures. In: King J and Pienaar H (eds.) Sustainable Use of South Africa's Inland Waters. WRC Report TT 491/11. Water Research Commission, Pretoria.

PRAT N, GALLART F, VON SCHILLER D, POLESELLO S, GARCIAROGER EM, LATRON J, RIEDEVALL M, LLORENS P, BARBERA GG, BRITO D and co-authors (2014) The Mirage Toolbox: An integrated assessment tool for temporary streams. River Res. Appl. 30 (10) 1318-1334. http://dx.doi.org/10.1002/rra.2757

PRUCHA RH, GRAHAM D, WATSON M, AVENANT MF, ESTERHUYSE S, JOUBERT A, KEMP M, KING J, LE ROUX P, REDELINGHUYS N and co-authors (2016) MIKE-SHE Integrated groundwater and surface water model used to simulate scenario hydrology for input to DRIFT-ARID. The Mokolo River case study. Water SA 42 (3) 384-398.

PUCKRIDGE JT, WALKER, KF and COSTELLOE JF (2000) Hydrological persistence and the ecology of dryland rivers. Regul. Rivers: Res. Manage. 16 385-402. http://dx.doi.org/10.1002/10991646(200009/10)16:5<385::AID-RRR592>3.0.CO;2-W 
RIVERS FOR AFRICA, EFLOW CONSULTING (PTY) LTD (2013) UNDP-GEF Orange-Senqu Strategic Action Programme. River EFR Assessment. Volume 1 and 2. Determination of the Fish River EFR and supporting information. Research project on environmental flow requirements of the Fish and the Orange-Senqu River mouth. ORASECOM.

ROSSOUW L, AVENANT MF, SEAMAN MT, KING JM, BARKER CH, DU PREEZ PJ, PELSER AJ, ROOS JC, VAN STADEN JJ, VAN TONDER GJ and co-authors (2005) Environmental water requirements in non-perennial systems. WRC Report No. 1414/1/05. Water Research Commission, Pretoria.

ROWNTREE KM and WADESON RA (1999) A hierarchical geomorphological model for the classification of selected South African rivers. WRC Report No. 497/1/99. Water Research Commission, Pretoria.

SEAMAN MT, AVENANT MF, WATSON M, KING J, ARMOUR J, BARKER CH, DOLLAR E, DU PREEZ PJ, HUGHES D, ROSSOUW $\mathrm{L}$ and co-authors (2010) Developing a method for determining the environmental water requirements for non-perennial systems. WRC Report No. TT 459/10. Water Research Commission, Pretoria. URL: http://www.wrc.org.za/Pages/DisplayItem.aspx?ItemID=8847\&FromU $\mathrm{RL}=\% 2 \mathrm{fPages} \% 2 \mathrm{fKH}$ _AdvancedSearch.aspx\%3fdt\%3d\%26ms\%3d\%26 $\mathrm{d} \% 3 \mathrm{dDeveloping}+\mathrm{a}+$ method+for+determining+the+environmental+ water+requirements+for+non-perennial+systems $\% 26$ start $\% 3 \mathrm{~d} 1$.

SEAMAN MT, WATSON M, AVENANT MF, JOUBERT AR, KING JM, BARKER CH, ESTERHUYSE S, GRAHAM D, KEMP ME, LE ROUX PA and co-authors (2013) Testing a methodology for environmental water requirements in non-perennial rivers. The Mokolo River Case Study. WRC Report No. TT579/13. Water Research Commission, Pretoria. URL: http://www.wrc.org.za/Pages/DisplayItem.aspx?I temID=10703\&FromURL=\%2fPages\%2fKH_AdvancedSearch. aspx $\% 3 \mathrm{fdt} \% 3 \mathrm{~d} \% 26 \mathrm{~ms} \% 3 \mathrm{~d} \% 26 \mathrm{~d} \% 3 \mathrm{dTesting}+\mathrm{a}+$ Methodology+for+En vironmental+Water+Requirements+in+Non-perennial+Rivers $\% 3 \mathrm{a}+\mathrm{T}$ he+Mokolo+River+Case+Study $\% 26$ start $\% 3 \mathrm{~d} 1$
SEAMAN MT, WATSON M, AVENANT MF, KING JM, JOUBERT AR, BARKER CH, ESTERHUYSE S, GRAHAM D, KEMP ME, LE ROUX PA and co-authors (2016) DRIFT-ARID. Application of a methodology for environmental water requirements (EWRs) in a non-perennial river (Mokolo River) in South Africa. Water SA 42 (3) 368-383.

SHELDON F (2005) Incorporating natural variability into the assessment of ecological health in Australian dryland rivers. Hydrobiologia 552 45-56. http://dx.doi.org/10.1007/s10750-005-1504-7

SHELDON F, BOULTON AJ and PUCKRIDGE JT (2002) Conservation value of variable connectivity: aquatic invertebrate assemblages of channel and floodplain habits of a central Australian arid-zone river, Cooper Creek. Biol. Conserv. 103 13-31. http://dx.doi.org/10.1016/ S0006-3207(01)00111-2

SHELDON F, BENN SE, HUGHES JM, ARTHINGTON AH, BALCOMBE SR and FELLOWS CS (2010) Ecological roles and threats to aquatic refugia in arid landscapes: Dryland river waterholes. Mar. Freshwater Res. 61 885-895. http://dx.doi.org/10.1071/mf09239

STEWARD AL, VON SCHILLER D, TOCKNER K, MARSHALL JC and BUNN SE (2012) When the river runs dry: human and ecological values of dry riverbeds. Front. Ecol. Environ. 10 (4) 202-209. http:// dx.doi.org/10.1890/110136

TOOTH S (2000) Process, form and change in dryland rivers: a review of recent research. Earth-Sci. Rev. 51 (1) 67-107. http://dx.doi. org/10.1016/S0012-8252(00)00014-3

WILLIAMS WD (1988) Limnological imbalances: An antipodean viewpoint. Freshwater Biol. 20 407-420. http://dx.doi. org/10.1111/j.1365-2427.1988.tb00466.x

UYS MC (1998) The ecology of temporary streams in the Eastern Cape. $\mathrm{PhD}$ thesis, Rhodes University, Grahamstown. 